\title{
Long-term outcomes of surgical treatment of patients with tibial plateau fractures repaired with llizarov external fixation
}

\author{
A.G. Karasev, A.S. Zhdanov, E.O. Darvin, T.Yu. Karaseva, I.V. Sutyagin, A.V. Lushnikov
}

Ilizarov National Medical Research Centre for Traumatology and Orthopedics, Kurgan, Russian Federation

\begin{abstract}
Introduction Fractures of the tibial plateau are classified by the location of the fracture line, associated capsular ligamentous injuries to the knee and can result from different types of high - or low-energy mechanisms of injury in patients of any age with different bone quality. These factors are responsible for different long-term functional outcomes and the lack of a generally accepted algorithm for diagnosis and treatment. The objective of the study was to analyze the long-term functional outcomes in patients with tibial plateau fractures treated with the Ilizarov external fixation. Material and methods The review included long-term outcomes of 59 patients with tibial plateau fractures treated with the Ilizarov external fixator. Long-term results were evaluated in 53 patients out of 59 (89.83 $\%$ ) using a subjective and objective clinical assessment system. The follow-up period ranged from 2 to 4 years. Patients were requested to complete the Oxford Knee Score questionnaire used in subjective outcome. Results Knee joint function of patients with tibial plateau fractures treated with the Ilizarov external fixation were rated as satisfactory $(\mathrm{n}=34 ; 64.15 \%) ; 16(30.19 \%)$ and $3(5.66 \%)$ patients were diagnosed with mild and moderate gonarthrosis, respectively. No infection that would affect the outcome was recorded in the study group. The mean Oxford Knee Score was $43.06 \pm 3.44$ (SD) in Schatzker type I split fractures of the lateral femoral condyle; $40.50 \pm 5.57$ (SD) in Schatzker type II split fractures combined with lateral articular surface depression; $40.71 \pm 4.27$ (SD) in Schatzker type III depression fractures; $42.33 \pm 4.22$ (SD) in Schatzker type IV medial condylar fractures; $38.50 \pm 7.19$ (SD) in Schatzker type V bicondylar fractures and $37.50 \pm 5.17$ (SD) in Schatzker type VI bicondylar fractures with dissociation of the metaphysis and diaphysis. Conclusions Tibial plateau fractures can be treated with the Ilizarov external fixation and also with the use of screws at any point of time that allows closed or open reduction of the fracture to ensure the early function of the operated limb, stable bone fixation, control of the fixation stiffness at any stage of treatment facilitating good and excellent functional outcomes.
\end{abstract}

Keywords: tibial plateau fracture, Ilizarov external fixation

\section{INTRODUCTION}

Tibial plateau fractures are severe intra-articular injuries characterized by impaired integrity of the articular surface and the metaepiphyseal cancellous bone of different severity. Tibial condyle fractures normally result in posttraumatic arthritis $[1,2,3]$ due to the injury to articular surfaces and to the capsular ligaments of the knee joint of different severity. The synovial fluid penetrating into the interstitial diastasis [4] affects fracture consolidation. Tibial plateau fractures require anatomical reduction and stable fixation like all intra-articular fractures, and surgical treatment should be performed as early as possible [2, 5]. Fracture location in the anatomical structures of the knee joint and the pathomechanics account for a high frequency of associated ligament and meniscus injuries [6, 7, 8] that significantly complicate surgical intervention and exacerbate the prognosis $[9,10]$. In addition to bone reduction and fixation tibial plateau fractures require early mobilization of the knee joint that can be challenging with injured ligaments and meniscus. Plates and screws, and external fixation devices [11-27] are the most common approaches used in the fixation of tibial plateau fractures. Ilizarov external fixation facilitates both closed and open reduction to address the bone defect with depressed articular surface. The indications to the two surgical approaches are controversial considering the benefits and disadvantages of both. Despite the variety of implants, plates and techniques of transosseous osteosynthesis there is no integrated algorithm for diagnosis and treatment of tibial plateau fractures with a high rate of adverse outcomes $[1,2,5$, $10,14,28,29,30,31]$.

The objective of the study was to analyze the long-term functional outcomes in patients with tibial plateau fractures treated with the Ilizarov external fixation depending on fracture patterns.

\section{MATERIAL AND METHODS}

Design: controlled, open, retrospective, monocenter, non-randomized study. Statistical data analysis was performed using Microsoft ${ }^{\circledR}$ Excel 16.16.25 (200810). The review included 67 patients with tibial plateau fractures treated at trauma and orthopaedic departments No. 1 and No. 2 of the National Ilizarov Medical
Research Center between 2014 and 2018. Inclusion criteria were surgical treatment of patients with tibial plateau fractures using the Ilizarov external fixation, combined osteosynthesis with screws, intramedullary wires and the Ilizarov frame. Exclusion criteria were the lack of information for outcome evaluation, plating

Marasev A.G., Zhdanov A.S., Darvin E.O., Karaseva T.Yu., Sutyagin I.V., Lushnikov A.V. Long-term outcomes of surgical treatment of patients with tibial plateau fractures repaired with Ilizarov external fixation. Genij Ortopedii, 2021, vol. 27, no 3, pp. 313-318. DOI 10.18019/1028-4427-2021-27-3-313-318 
of the tibial plateau fracture. Based on the criteria 8 patients were excluded from the study and the review included 59 patients. The age of patients ranged from 20 to 78 years. There were $67 \%$ patients of working age, $45.6 \%$ males and $54.4 \%$ females. Radiographs were performed for all patients preoperatively, intraoperatively, postoperatively, at one week after the operation and after removal of the Ilizarov frame. Computed tomography (CT) or multispiral computed tomography (MSCT) of the proximal tibia were produced for 19 patients with suspected joint surface depression and a subchondral cancellous bone defect for preoperative planning. Short-term outcomes of surgical treatment were evaluated radiologically. Schatzker type I fractures of the lateral condyle without depression were identified in most cases with the analysis of the location of injury (Table 1). The Schatzker classification was used in the review [3].

Ilizarov external fixation was performed for 59 patients [22]. From them, two had open reduction and two had bone defect repaired with autograft harvested from the iliac crest. Ilizarov external fixation was added by using a cancellous screw $(\mathrm{n}=1)$, and by intramedullary Kirshner wires $(\mathrm{n}=1)$ (Tables 2 and 3).

Skeletal traction with a wire placed in the distal metaepiphysis of the tibia was performed for patients after diagnosis and preoperative preparation. Reference rings with two to three transosseous wires attached were placed at the level of the middle third of the tibial shaft. A ring with two to three olive wires was placed at the level of tibial condyles for bone fixation and reduction. Distraction was provided first and bone reduction produced with olive wires after correction of the lower limb axis. Collateral and cruciate ligaments were clinically tested for injury after bone reduction and removal of the skeletal traction. A reference ring with two to three transosseous wires was placed at the level of the femoral condyles in case of clinically pronounced instability of the knee joint. The proximal reference ring and the fixation-reduction ring were stiffly connected by three hinges at $30^{\circ}$ flexion to span the knee joint. If the ligaments of the knee joint were intact, the frame was mounted to the tibia only to allow motion in the knee joint from the second postoperative day. The fracture was normally fixed with the Ilizarov frame for 2 to 3 months depending on the severity of injury and the clinical and radiological picture. A 8-10 $\mathrm{cm}$ approach was performed anterolaterally for depressed articular surface of the lateral condyle and medially for the medial location. A longitudinal 8-10 $\mathrm{cm}$ approach to the wing of the contralateral ilium was performed after visualization of the fracture site and assessment of the defect size. Then the iliac wing was finally osteotomized so that to size up the defect.
The autograft was placed in the bed, the fracture reduced, and depression of the articular surface was addressed with transosseous olive wires or Kirschner IM wires to duplicate the fixation and reduction of the transosseous components for smaller fragments and/or severe osteoporosis. Condylar fragments were fixed with cancellous screws in case of a failed condylar reduction following eliminated depression of the articular surface or in a delayed case.

Table 1

Distribution of patients with tibial plateau fractures using the Schatzker classification

\begin{tabular}{|c|c|c|}
\hline \multirow{2}{*}{$\begin{array}{c}\text { Type of fracture classified with } \\
\text { Schatzker grading system }\end{array}$} & \multicolumn{2}{|c|}{ Number of cases } \\
\cline { 2 - 3 } & abs. & $\%$ \\
\hline I & $18(17)$ & $30.5(94.4)$ \\
\hline II & $8(8)$ & $13.5(87.5)$ \\
\hline III & $7(7)$ & $11.9(85.7)$ \\
\hline IV & $11(9)$ & $18.6(81.8)$ \\
\hline V & $11(8)$ & $18.6(72.7)$ \\
\hline VI & $4(4)$ & $6.9(100)$ \\
\hline
\end{tabular}

Note: brackets include patients with available long-term follow-up

Table 2

Distribution of patients by operative techniques used

\begin{tabular}{|l|l|c|c|}
\hline \multirow{2}{*}{ Type of surgical procedure applied } & \multicolumn{2}{|c|}{ Number of patients } \\
\cline { 3 - 4 } & abs. & $\%$ \\
\hline \multirow{2}{*}{$\begin{array}{l}\text { Ilizarov external } \\
\text { fixation }\end{array}$} & OR & 53 & 89.8 \\
\cline { 2 - 4 } & OR and AG & 2 & 3.4 \\
\hline $\begin{array}{l}\text { Ilizarov external } \\
\text { fixation combined } \\
\text { with screws }\end{array}$ & OR & 1 & 1.7 \\
\cline { 2 - 4 } & OR and AG & 1 & 1.7 \\
\hline
\end{tabular}

Notes for Tables 2 and 3: CT - closed technique ; OR, open reduction; $\mathrm{OR}$ and $\mathrm{AG}$, open reduction and autograft

Table 3

Distribution of patients by operative techniques used with regard to the fracture classified with Schatzker grading system

\begin{tabular}{|c|c|c|c|c|c|c|c|}
\hline \multirow{2}{*}{\multicolumn{2}{|c|}{$\begin{array}{l}\text { Type of surgical } \\
\text { procedure produced }\end{array}$}} & \multicolumn{6}{|c|}{$\begin{array}{l}\text { Fracture pattern classified with } \\
\text { Schatzker grading system }\end{array}$} \\
\hline & & I & \begin{tabular}{|l|} 
II \\
\end{tabular} & III & IV & $\mathrm{V}$ & VI \\
\hline \multirow{3}{*}{$\begin{array}{l}\text { Ilizarov } \\
\text { external } \\
\text { fixation }\end{array}$} & $\mathrm{CT}$ & $18(17)$ & $6(5)$ & $5(4)$ & $10(8)$ & $8(5)$ & $4(4)$ \\
\hline & OR & - & $1(1)$ & - & - & - & - \\
\hline & OR and $A G$ & - & $1(1)$ & $2(2)$ & $1(1)$ & $1(1)$ & - \\
\hline \multirow{2}{*}{$\begin{array}{l}\text { Ilizarov } \\
\text { external } \\
\text { fixation } \\
\text { combined } \\
\text { with plating }\end{array}$} & OR & - & - & - & - & - & - \\
\hline & $\mathrm{OR}$ and $\mathrm{AG}$ & - & - & - & - & $2(2)$ & - \\
\hline
\end{tabular}

Note: brackets include patients with available long-term follow-up

The knee was spanned for 3 to 6 weeks for injured ligaments and unstable joint to facilitate full weightbearing on the operated limb. Physical therapy could be initiated with the spanned knee joint using the Ilizarov external fixation twice a day through loosening the hinges for exercises. Physiotherapist assisted active 
and/or passive movements in the knee joint, and the hinges were tightened back after the session.

Clinical instances are presented in Figures 1, 2, and 3.

Short-term outcomes (up to 1 year) were documented at follow-up visits and were available in all 59 cases. Radiographic anteroposterior and lateral views were used to assess fracture consolidation and rule out secondary displacement. The fracture was also tested clinically for coronal and/or sagittal instability of the knee joint. Two Schatzker type II and $\mathrm{V}$ patients $(3.4 \%)$ showed residual coronal
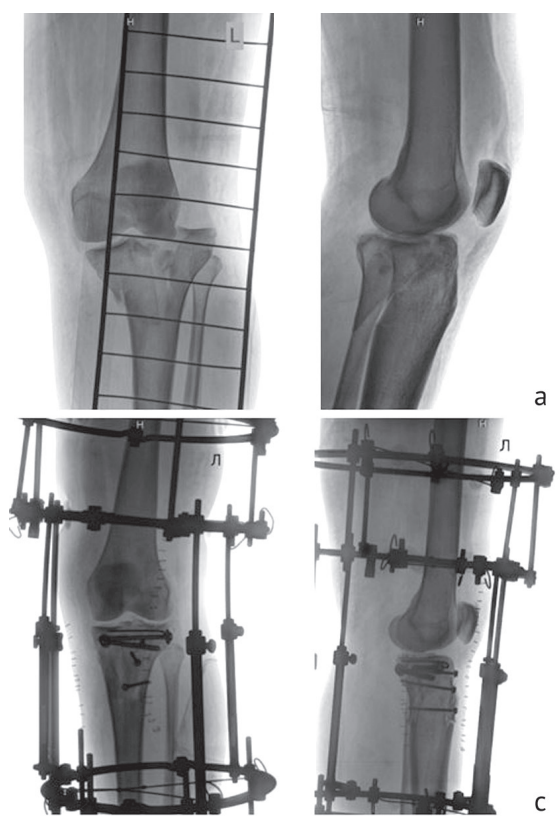

instability of the knee joint, and a Schatzker type VI patient (1.7 \%) demonstrated sagittal knee instability. Fusion was achieved in all patients. 35 $(59.3 \%)$ patients presented no complaints at the follow-up visits, $14(23.7 \%)$ reported pain and mild fatigue after prolonged walking, 10 patients retained swelling at the knee joint. Moderate osteoporosis was radiologically detected in $8(13.5 \%)$ patients and the callosity of the rest patients was significantly densed and measured up to the density of the surrounding bone or significantly approached to it.

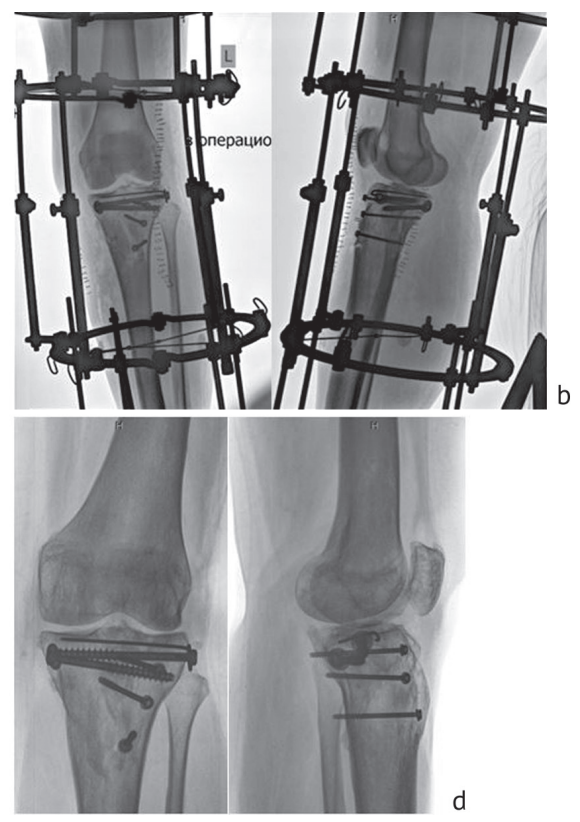

Fig. 1 Radiographs of the knee joint of a 51-year-old patient S. diagnosed with fracture of the medial tibial condyle, intercondylar eminence, depression Schatzker type V fracture of the lateral tibial condyle showing (a) preoperative view; (b) open reduction of the left tibial condyles, autografting performed with the graft harvested from the iliac wing, fixation of the knee with cancellous and cortical screws and the Ilizarov frame (2 days of injury); (c) prior to discharge from the hospital (24 days of injury); (d) frame removed (54 days of injury)
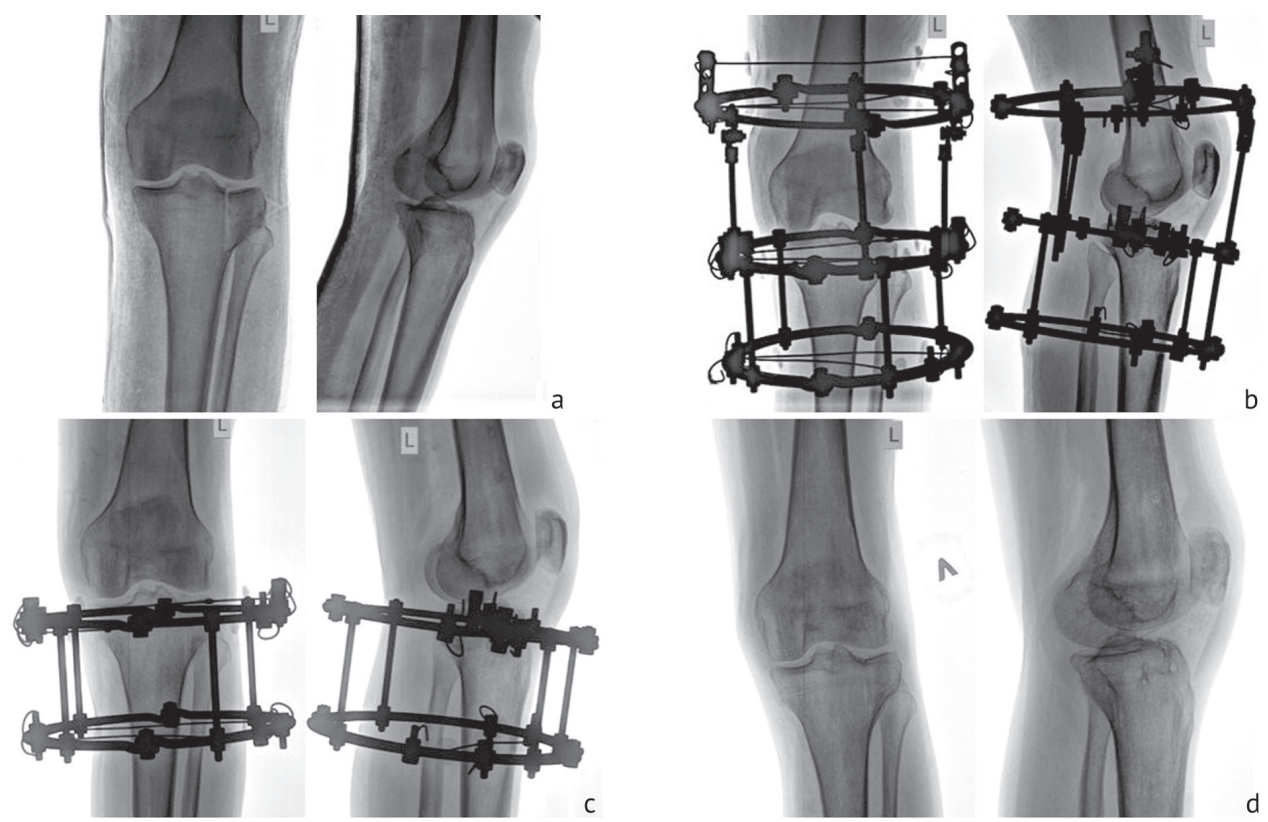

Fig. 2 Radiographs of the knee joint of a 67-year-old patient P. diagnosed with displaced Schatzker type I fracture of the lateral tibial condyle showing (a) preoperative view; (b) closed application of the Ilizarov frame to the left tibia spanning the knee joint (4 days of injury); (c) proximal reference ring removed and the knee mobilized (39 days of injury); (d) frame removed (64 days of injury) 

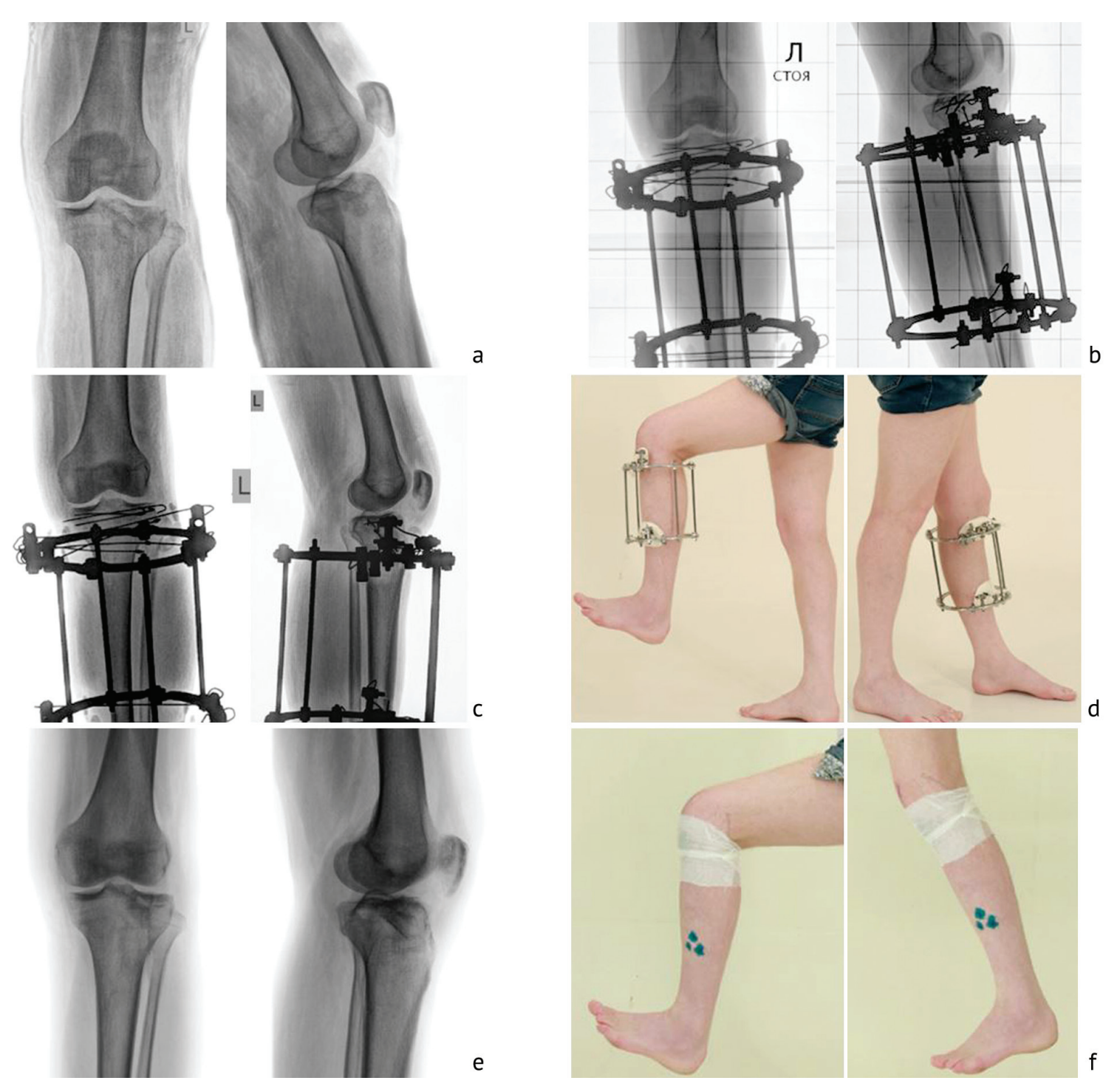

Fig. 3 Radiographs and photographs of a 37-year-old patient M. diagnosed with displaced depression Schatzker type II fracture of the lateral tibial condyle showing (a) preoperative view; (b) open reduction of the left tibial condyles, autografting performed with the graft harvested from the iliac wing, fixation of the knee with the Ilizarov frame ( 9 days of injury); (c, d) 36 days of injury; (e, f) frame removed (127 days of injury)

Long-term results were evaluated in 53 patients out of $59(89.83 \%)$. The follow-up period ranged from 2 to 4 years. The outcomes were assessed with subjective and objective clinical tests. The Oxford Knee Score questionnaire was used for subjective assessment of outcomes [32].

\section{RESULTS}

Patients with of the tibial plateau fractures treated mild gonarthrosis $(\mathrm{n}=16 ; 30.19 \%)$ and moderate with the Ilizarov external fixation showed satisfactory gonarthrosis $(n=3 ; 5.66 \%)$ (Table 4). None of the knee joint function $(\mathrm{n}=34 ; 64.15 \%)$; developed patients developed infection.

Table 4

Analysis of long-term functional outcomes measured in patients with Schatzker types fractures using the Oxford Knee Score

\begin{tabular}{|c|c|}
\hline Schatzker types fracture & Long-term functional outcomes measured with the Oxford Knee Score \pm SD \\
\hline I & $43.06 \pm 3.44$ \\
\hline II & $40.50 \pm 5.57$ \\
\hline III & $40.71 \pm 4.27$ \\
\hline IV & $42.33 \pm 4.22$ \\
\hline V & $38.50 \pm 7.19$ \\
\hline VI & $37.50 \pm 5.17$ \\
\hline
\end{tabular}




\section{DISCUSSION}

The success of treatment of patients with tibial plateau fractures depends on:

1) type of fracture - presence or absence of a depression of the articular surface, concomitant injury to the ligaments, meniscus $[2,6]$;

2) accurate diagnosis of all injuries and welldeveloped treatment strategy [5];

3) timing of the surgical intervention [33];

4) patient's age, preoperative functional status [15];

5) quality of bone reduction: restoration of the limb axis, anatomical reposition of articulating surfaces, repair of bone defects $[5,17,34]$;

6) rehabilitation: active movements during comprehensive physical therapy, unassisted walking [21].

Shatzker types I, IV, V fractures (without depression) and Shatzker type IV can be reduced in a closed manner using the Ilizarov external fixation device. Schatzker type II and III fractures associated with a significant depression of the articular surface require open reduction, elevation of the depressed articular surface and repair of the bone defect. Open reduction can be produced either with external fixation or with screws. The combined use of external fixation and screws can facilitate good long-term results. The best outcomes were achieved in patients with single-condylar split Schatzker type I and IV fractures that were repaired in the first days of injury and could be easily reduced in a closed manner. With less traumatic intervention and a high preoperative functional level patients could initiate rehabilitation on the second postoperative day through walking with weight-bearing on the injured limb, active and passive exercises in the knee and adjacent joints with the fracture fixed with the Ilizarov frame and continue the sessions throughout the entire period of treatment. The worst results of treatment were seen in patients with comminuted and/or depression Schatzker type V and VI fractures of both condyles that were difficult for accurate reduction due to smaller bone fragments and a subchondral defect. In addition to that, injuries to the cruciate and collateral ligaments that occur in nearly all fracture patterns [35] are associated with less rewarding functional results of treatment and can be addressed after fracture healing that would take 3 to 4 months. Despite the challenges with comminuted fractures of both tibial condyles adequate reduction and early functional loading on the limb fixed with the Ilizarov apparatus allows fracture consolidation and prevention of secondary bone displacement. Ilizarov external fixation of complicated Schatzker type V and VI plateau fractures can be used at any point of injury, with compromised skin over the fracture site providing good and satisfactory functional outcomes.

\section{CONCLUSION}

1. Anatomical reduction, stable fixation and early functional loading on the limb facilitate good and excellent functional outcomes for the tibial plateau fractures repaired with the Ilizarov frame.

2. Tibial plateau fractures can be treated with the Ilizarov external fixation at any point of time that allows closed or open reduction of the fracture to ensure stable bone fixation, control of the fixation stiffness at any stage of treatment.

3. Open reduction with external fixation and a combination of fixation methods can provide good functional results.

\section{REFERENCES}

1. Kettelkamp D.B., Hillberry B.M., Murrish D.E., Heck D.A. Degenerative arthritis of the knee secondary to fracture malunion. Clin. Orthop. Relat. Res., 1988, no. 234, pp. 159-169.

2. Lachiewicz P.F., Funcik T. Factors influencing the results of open reduction and internal fixation of tibial plateau fractures. Clin. Orthop. Relat. Res., 1990, no. 259, pp. 210-215.

3. Schatzker J. Compression in the surgical treatment of fractures of the tibia. Clin. Orthop. Relat. Res., 1974, no. 105, pp. $220-239$.

4. Berkson E.M., Virkus W.W. High-energy tibial plateau fractures. J. Am. Acad. Orthop. Surg., 2006, vol. 14, no. 1, pp. 20-31. DOI: 10.5435/00124635200601000-00005

5. Egol K.A., Tejwani N.C., Capla E.L., Wolinsky P.L., Koval K.J. Staged management of high-energy proximal tibia fractures (OTA types 41): the results of a prospective, standardized protocol. J. Orthop. Trauma, 2005, vol. 19, no. 7, pp. 448-456. DOI: 10.1097/01.bot.0000171881.11205.80

6. Delamarter R.B., Hohl M., E. Hopp Jr. Ligament injuries associated with tibial plateau fractures. Clin. Orthop. Relat. Res., 1990, no. 250 , pp. $226-233$.

7. Gardner M.J., Yacoubian S., Geller D., Suk M., Mintz D., Potter H., Helfet D.L., Lorich D.G. The incidence of soft tissue injury in operative tibial plateau fractures. A magnetic resonance imaging analysis of 103 patients. J. Orthop Trauma, 2005, vol. 19, no. 2, pp. 79-84. DOI: 10.1097/00005131200502000-00002

8. Gardner M.J., Yacoubian S., Geller D., Pode M., Mintz D., Helfet D.L., Lorich D.G. Prediction of soft-tissue injuries in Schatzker II tibial plateau fractures based on measurements of plain radiographs. J. Trauma, 2006, vol. 60, no. 2, pp. 319-323. DOI: 10.1097/01.ta.0000203548.50829.92

9. Bhattacharyya T., McCarty L.P. 3rd, Harris M.B., Morrison S.M., Wixted J.J., Vrahas M.S., Smith R.M. The posterior shearing tibial plateau fracture: treatment and results. J. Orthop. Trauma, 2005, vol. 19, no. 5, pp. 305-310.

10. Cole P.A., Zlowodzki M., Kregor P.J. Treatment of proximal tibia fractures using the less invasive stabilization system: surgical experience and early clinical results in 77 fractures. J. Orthop. Trauma, 2004, vol. 18, no. 8, pp. 528-535. DOI: 10.1097/00005131-200409000-00008

11. Ali A.M., Saleh M., Bolongaro S., Yang L. The strength of different fixation techniques for bicondylar tibial plateau fractures - a biomechanical study. Clin. Biomech., 2003, vol. 18, no. 9, pp. 864-870. DOI: 10.1016/s0268-0033(03)00149-9 
12. Ali A.M., Yang L., Hashmi M., Saleh M. Bicondylar tibial plateau fractures managed with the Sheffield Hybrid Fixator. Biomechanical study and operative technique. Injury, 2001, vol. 32, no. Suppl 4, pp. 86-91. DOI: 10.1016/s0020-1383(01)00165-6

13. Ballmer F.T., Hertel R., Nötzli H.P. Treatment of tibial plateau fractures with small fragment internal fixation: a preliminary report. J. Orthop. Trauma, 2000, vol. 14, no. 7, pp. 467-474. DOI: 10.1097/00005131-200009000-00002

14. Barei D.P., Nork S.E., Mills W.J., Henley M.B., Benirschke S.K. Complications associated with internal fixation of high-energy bicondylar tibial plateau fractures utilizing a two-incision technique. J. Orthop. Trauma, 2004, vol. 18, no. 10, pp. 649-657. DOI: 10.1097/00005131-200411000-00001

15. Barei D.P., Nork S.E., Mills W.J., Coles C.P., Henley M.B., Benirschke S.K. Functional outcomes of severe bicondylar tibial plateau fractures treated with dual incisions and medial and lateral plates. J. Bone Joint Surg. Am., 2006, vol. 88, no. 8, pp. 1713-1721. DOI: 10.2106/JBJS.E.00907

16. Watson J.T., Ripple S., Hoshaw S.J., Fhyrie D. Hybrid external fixation for tibial plateau fractures: clinical and biomechanical correlation. Orthop. Clin. North Am., 2002, vol. 33, no. 1, pp. 199-209. DOI: 10.1016/s0030-5898(03)00080-4

17. Marsh J.L., Buckwalter J., Gelberman R., Dirschl D., Olson S., Brown T., Llinias A. Articular fractures: does an anatomic reduction really change the result? J. Bone Joint Surg. Am., 2002, vol. 84, no. 7, pp. 1259-1271.

18. Mueller C.A., Eingartner C., Schreitmueller E., Rupp S., Goldhahn J., Schuler F., Weise K., Pfister U., Suedkamp N.P. Primary stability of various forms of osteosynthesis in the treatment of fractures of the proximal tibia. J. Bone Joint Surg. Br., 2005, vol. 87, no. 3, pp. 426-432. DOI: 10.1302 /0301-620x.87b3.14353

19. Mueller K.L., Karunakar M.A., Frankenburg E.P., Scott D.S. Bicondylar tibial plateau fractures: a biomechanical study. Clin. Orthop. Relat. Res., 2003, no. 412, pp. 189-195. DOI: 10.1097/01.blo.0000071754.41516.e9

20. Karasev E.A. Kombinirovannoe primenenie artroskopii i metoda chreskostnogo osteosinteza pri lechenii bolnykh s povrezhdenizami i zabolevaniiami kolennogo sustava. Diss. kand. med. nauk [Combined use of arthroscopy and transosseous osteosynthesis method in treatment of the patients with the knee injuries and diseases. Cand. med. sci. diss.]. Kurgan, 2010, 165 p. (in Russian)

21. Shevtsov V.I., Karaseva T.Iu., Karasev E.A. Lechenie bolnykh s zakrytymi vnutrisustavnymi perelomami myshchelkov bolshebertsovoi kosti (metod. rekomendatsii [Treatment of patients with closed intra-articular fractures of tibial condyles. A technique manual]. Kurgan, RNTs «VTO» im. akad. G.A. Ilizarova, 2012, 10 p. (in Russian)

22. Noskov V.K. Zakrytyi chreskostnyi osteosintez po Ilizarovu pri perelomakh myshchelkov bedrennoi i bolshebertsovoi kostei. Avtoref. diss. kand. med. nauk [Closed transosseous osteosynthesis according to Ilizarov for fractures of the femoral and tibial condyles. Cand. med. sci. diss. abstr.]. Perm, 1986,17 p. (in Russian)

23. Shevtsov V.I., Karasev A.G., Karaseva T.Iu., Karasev E.A. Primenenie kombinirovannoi metodiki pri lechenii bolnoi s nestabilnym vnutrisustavnym perelomom plato bolshebertsovoi kosti [Combined technique used for treatment of a female patient with unstable intraarticular fracture of tibial plateau]. Genij Ortopedii, 2009, no. 3, pp. 127-129. (in Russian)

24. Shved S.I., Karagodin G.E., Noskov V.K. Sposob lecheniia perelomov myshchelkov bedrennoi i bolshebertsovoi kostei metodom chreskostnogo osteosinteza [The technique of treating fractures of the femur and tibia by transosseous osteosynthesis method]. Ortopediia, Travmatologiia $i$ Protezirovanie, 1986, no. 2, pp. 42-43. (in Russian)

25. Egol K.A., Su E., Tejwani N.C., Sims S.H., Kummer F.J., Koval K.J. Treatment of complex tibial plateau fractures using the less invasive stabilization system plate: clinical experience and a laboratory comparison with double plating. J. Trauma, 2004, vol. 57, no. 2, pp. 340-346. DOI: $10.1097 / 01$. ta.0000112326.09272.13

26. Manikandan N., Saravanakumar K.P. A study on functional and radiological outcome of complex tibial plateau fractures by posteromedial plating. Int. J. Res. Orthop., 2019, vol. 5, no. 2, pp. 223-226. DOI: 10.18203/issn.2455-4510

27. Mallik A.R., Covall D.J., Whitelaw G.P. Internal versus external fixation of bicondylar tibial plateau fractures. Orthop. Rev., 1992, vol. 21, no. 12, pp. 1433-1436.

28. Cole P.A., Zlowodzki M., Kregor P.J. Less Invasive Stabilization System (LISS) for fractures of the proximal tibia: indications, surgical technique and preliminary results of the UMC clinical trial. Injury, 2003, vol. 34, no. Suppl. 1, pp. A16-A29. DOI: 10.1016/s0020-1383(03)00254-7

29. Hap D.X.F., Kwek E.B.K. Functional outcomes after surgical treatment of tibial plateau fractures. J. Clin. Orthop. Trauma, 2020, vol. 11, no. Suppl. 1, pp. S11-S15. DOI: $10.1016 /$ j.jcot.2019.04.007

30. Rasmussen P.S. Tibial condylar fractures. Impairment of knee joint stability as an indication for surgical treatment. J. Bone Joint Surg. Am., 1973, vol. 55 , no. 7, pp. 1331-1350.

31. Van Dreumel R.L., Van Wunnik B.P., Janssen L., Simons P.C., Janzing H.M. Mid- to long-term functional outcome after open reduction and internal fixation of tibial plateau fractures. Injury, 2015, vol. 46, no. 8, pp. 1608-1612. DOI: 10.1016/j.injury.2015.05.035

32. Dawson J., Fitzpatrick R., Murray D., Carr A. Questionnaire on the perceptions of patients about total knee replacement. J. Bone Joint Surg. Br., 1998, vol. 80, no. 1, pp. 63-69. DOI: 10.1302/0301-620x.80b1.7859

33. Court-Brown C.M., Heckman J.D., McQueen M.M., Ricci W.M., Tornetta P. III. Rockwood and Green's fractures in adults. $8^{\text {th }}$ Ed. McKee M., editor. Philadelphia, Lippincott Williams \& Wilkins/Wolters Kluwer Health, 2015, pp. 2326-2329, 2358.

34. Weigel D.P., Marsh J.L. High-energy fractures of the tibial plateau. Knee function after longer follow-up. J. Bone Joint Surg. Am., 2002, vol. 84, no. 9, pp. 1541-1551. DOI: 10.2106/00004623-200209000-00006

35. Mustonen A.O., Koivikko M.P., Lindahl J., Koskinen S.K. MRI of acute meniscal injury associated with tibial plateau fractures: prevalence, type and location. AJR Am. J. Roentgenol., 2008, vol. 191, no. 4, pp. 1002-1009. DOI: 10.2214/AJR.07.3811

Received: 23.11 .2020

\section{Information about the authors:}

1. Anatoly G. Karasev, M.D., Ph.D.,

Ilizarov National Medical Research Centre for Traumatology and Orthopedics, Kurgan, Russian Federation

2. Alexey S. Zhdanov, M.D., Ph.D.,

Ilizarov National Medical Research Centre for Traumatology and Orthopedics, Kurgan, Russian Federation

3. Evgeniy O. Darvin, M.D., Ph.D.,

Ilizarov National Medical Research Centre for Traumatology and Orthopedics, Kurgan, Russian Federation

4. Tatiana Yu. Karaseva, M.D., Ph.D.,

Ilizarov National Medical Research Centre for Traumatology and Orthopedics, Kurgan, Russian Federation

5. Anton V. Lushnikov, M.D., Ph.D.,

Ilizarov National Medical Research Centre for Traumatology and Orthopedics, Kurgan, Russian Federation

6. Ilya V. Sutyagin, M.D., Ph.D.,

Ilizarov National Medical Research Centre for Traumatology and Orthopedics, Kurgan, Russian Federation,

Email: pr_sutyagin@bk.ru 